\title{
INFOGRAFIS PENCEGAHAN COVID 19 MELALUI EKSPLORASI DOKUMENTASI VIDEO PROJECTION MAPPING
}

\author{
1)Nur Rahmat Ardi Candra Dwi Atmaja ${ }^{2)}$ Johan les Wahyudi ${ }^{3)}$ Damar Tri Afrianto \\ ${ }^{1}$ Fakultas Seni Rupa Dan Desain, ISI Surakarta \\ email: nracandra@gmail.com \\ ${ }^{2}$ Fakultas Seni Rupa Dan Desain , ISI Surakarta \\ email: bangjosolo99@gmail.com \\ ${ }^{3}$ Fakultas Seni Rupa Dan Desain, ISI Surakarta \\ email: damar.tri.a@gmail.com
}

\begin{abstract}
The process of changing the initial shape of a facade into a new shape resulting in an optical illusion is an activity called Video Mapping. These objects will visually change from their usual form into a new form that is different and very fantastic. Projection mapping is a medium that can provide the audience with experience to feel three-dimensional effects in two-dimensional fields, or it can also be called immersive media. With the display of a projection mapping on a flat plane, it is possible to reach a wider segment of the material and content regarding government policies related to the Covid-19 preventive health protocol which can be displayed through projection video mapping media. Planning to create work for the Video Projection Mapping Documentation is none other than the departure from anxiety about the presence of conventional media and social media which report simply and monotonously related to government policies related to the prevention of Covid-19 and its health protocols. This is what causes people to just casually respond to the infographic because the content and visualization lack persuasive, dramatic and creative power. Because of this, a method of art creation is formulated in this artistic research, namely how to create infographics that emphasize new media as an alternative media for socializing government policies related to Covid-19 through the creation of the work Documentation Video Projection Mapping as an alternative media for the socialization of Covid-19 prevention.
\end{abstract}

Keywords: infografis, ekplorasi, video dokumentasi, projection mapping

\section{PENDAHULUAN}

Sederet daftar kematian, kehilangan, dan kerugian adalah catatan disetiap wabah yang melanda. Saat pandemi Corona Virus Desease -Tahun 2019 (Covid-19) menghantam penjuru dunia hingga ratusan negara, maka disetiap negara itu pun merumuskan berbagai strategi pencegahannya, tak terkecuali negara Indonesia. Sejak pertama diumumkan oleh Presiden Jokowi pada tanggal 1 Maret 2020 tentang mulai masuknya di Indonesia dengan diinformasian dua orang warga Depok, Jawa Barat yang telah positif terpapar Covid-19 ini. Virus ini penyebarannya begitu cepat hingga saat ini hampir terkonfirmasi muncul di 34 provinsi di Indonesia.

Strategi pencegahannya pun segera dilakukan oleh pemerintah dengan melibatkan kementerian-kementerian terkait sebagai bentuk protokol kesehatan terpusat dan resmi. Beberapa protokol kesehatan pencegahan Covid-19 ini muncul mulai dari adanya istilah work from home, learning from home, social distancing, physical distancing dan yang terakhir presiden mengeluarkan peraturan terkait pencegahan virus ini yaitu Pembatasan Sosial Berskal Besar (PSBB). Akhirnya, sebagaian daerah pun telah ada yang menerapkan kebijakan PSBB tadi seiring naiknya tingkat penyebaran Covid-19 yang telah sampai di daerah-daerah.

Kebijakan-kebijakan dari pemerintah tersebut tidak hanya cukup sebagai sebuah konsep aturan namun diperlukan kerja sama dari pusat dan masyarakat terkait optimalisasi kebijakan tersebut. Masyarakat dituntut harus benar-benar tahu, mengerti dan paham akan informasi-informasi penting terkait protokol kesehatan resmi dari pemerintah ini terkait pencegahan Covid-19 di Indonesia. Peran seluruh stakeholder di setiap lini di masyarakat tentunya juga harus bergandengan tangan turut berpartisipasi 
menyampaikan informasi yang benar tentang protokol kesehatan Covid- 19 ini.

Sampai saat ini berbagai pelanggaran atas protokol kesehatan masih kita temui, seperti contohnya pemerintah sudah meliburkan para siswa dan mahasiswa untuk tidak bersekolah atau pun berkuliah dan memberlakukan bekerja dari dalam rumah (Work From Home), namun kondisi ini malahan dimanfaatkan oleh banyak masyarakat untuk berlibur. Selain itu, walaupun Indonesia sudah dalam keadaan darurat masih saja ada beberapa lapisan masyarakat yang kedapatan akan melaksanakan sebuah tabliqh akbar, yang momen ini akan memunculkan sebuah situasi berkumpulnya ribuan orang di satu tempat, yang jelas hal ini dapat menjadi salah satu faktor resiko penyebab ternjadinya penyebaran Covid-19 dalam skala yang jauh lebih besar (https://nasional.tempo.co/ $\mathrm{read} / 1321285 /$ pandemi-corona-ribuan-orangikut- tabligh-akbar-se-asia-di-gowa). Bahkan karena memasuki Bulan Ramadhan, masyarakat mulai melakukan mudik diawal yang hal ini juga rentan akan penyebaran virus ini di daerah-daerah.

Pelanggaran atas kebijakan pemerintah terkait pencegahan Covid-19 tersebut kurang mendapat perhatian, sehingga setiap hari data korban atau pasien positif Covid- 19 di Indonesia secara akumulasi terus meningkat. Upaya sosialiasi melaui media terus dilakukan, baik media konvensional (Televisi, Koran, Poster, Radio) hingga media sosial daring yang dapat menjangkau semua lapisan masyarakat. Dengan meningkatnya berbagai macam pelanggaran atas kebijakan dan protokol kesehatan dari pemerintah maka sebagai konsekuensi logisnya dalam hal ini tentunya harus dipikirkan strategi sosialisan informasi pencegahan penyebaran Covid-19 ini dalam bentuk-bentuk yang lain dan mungkin lebih bervariasi.

Peran berbagai pihak terutama insan media menjadi penting dalam hal sosialisasi ini. Dalam rangka optimalisasi kebijakan pemerintah terkait pencegahan Covid-19 maka salah satu solusi yang akan ditawarkan dari kegiatan penelitan seni ini adalah sebuah penciptaan seni (artistik) yang direncanakan sebagai salah satu media efektif penyampaian informasi seputar pencegahan Covid-19 melalui ekplorasi dokumentasi video projection mapping.

Video Projection Mapping adalah media dinamis. Projection mapping merupakan sebuah teknik yang menggunakan pencahayaan dan proyeksi sehingga dapat menciptakan ilusi optis pada obyek-obyek. Video Projection Mapping juga merupakan sebuah seni pencahayaan yang melibatkan cahaya itu sendiri sebagai medianya (Sya'Roni, 2014: 10).

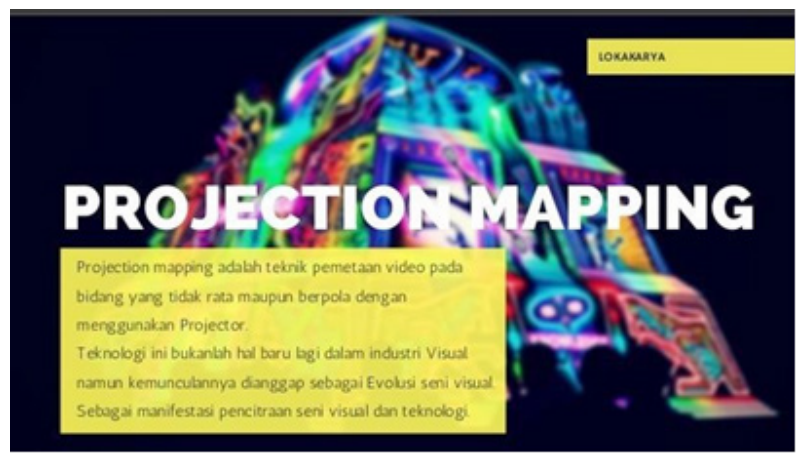

Gambar 1. Informasi tentang video projection mapping (www.slideshare.net)

Video Mapping merubah bentuk awal suatu fasad menjadi bentuk baru sehingga menghasilkan ilusi optik. Obyek-obyek tersebut secara visual akan berubah dari bentuk biasanya menjadi bentuk baru yang berbeda dan sangat fantastis. Projection mapping adalah media yang bisa memberikan pengalaman para audiens untuk merasakan efek tiga dimensi di bidang dua dimensi, atau bisa juga disebut dengan media immersive. Dengan ditampilkannya sebuah projection mapping pada bidang datar memungkinkan dapat menjangkau pada segmen yang lebih luas terkait materi dan konten tentang kebijakan pemerintah dan protokol kesehatan dapat ditampilkan melalui media projection video mapping.

Berkaitan dengan permasalahan di atas dirumuskan sebuah penelitian artistik yaitu bagaimana menciptakan infografis yang menekankan pada media baru sebagai media alternatif sosialisasi kebijakan pemerintah terkait Covid-19 dan bagiamana menciptakan karya Dokumetasi Video Projection Mapping sebagai media sosialisasi efektif Covid -19. Tujuan karya ini dibuat adalah memberikan solusi media infografis yang menekankan pada 
Infografis Pencegahan Covid 19 Melalui Eksplorasi Dokumentasi Video Projection Mapping - NRA Candra dkk

aspek kebaruan media sosialisasi, sehingga diharapkan kebijakan pemerintah terkait penanggulangan Covid-19 dan protokol kesehatan dapat menyentuh masyarakat.

Konsep karya ini adalah infografis Covid-19 dengan pendekatan dokumentasi video projection mapping. Dokumentasi video Projection mapping adalah metode baru yang merupakan bagian dari evolusi seni visual. Sebagai manifestasi pencitraan seni visual dan teknologi. Video maker dapat mewujudkan ide yang di desain ke dalam materi 3D apapun di dalam bentukan arsitektur. Projection mapping menggabungkan pemetaan film dan video lalu didokumentasikan ulang. Video Mapping yang direncanakan berbeda dengan video mapping pada umumnya secara penyajiannya.. Umumnya video mapping kita bisa saksikan hanya di tempat-tempat umum atau artsitektur bangunan, namun dalam perencanaan video projection mapping kali ini berbeda, aktivitas pemutaran video mapping akan didokumentasikan dalam bentuk video, kemudian akan di share melalui kanal-kanal media sosial. Sehingga kita dapat menyaksikan projection mapping dalam genggaman gawai di rumah saja. Proses tersebut mengandaikan dua aktivitas, yaitu pemutaran video projection mapping secara langsung di 'lapangan' atau lokasi yang telah dipilih lantas kemudian didokumentasikan. Hasil dari dokumetasi video projection mapping akan bisa ditonton pada perangkat gadget melalui akun-akun media sosial. Melalui kanal media sosial masyarakat dapat menikmati video mapping yang berisi materi dan konten terkait kebijakan-kebijakan pemerintah dalan penanggulangan covid-19 dan protokol kesehatan. Media baru ini diharapkan memberikan infografis alternative, selain video konvensional dan poster yang kerap membosankan karena bersifat statis.

Perencanaan Karya Dokumentasi Video Projection Mapping tak lain berangkat dari kegelisahan tentang hadirnya media-media konvensional dan media sosial yang memberitakan secara sederhana dan monoton terkait dengan kebijakan pemerintah terkait dengan penanggulangan Covid-19 beserta protokol kesehatannya. Inilah yang menyeabkan masyarakat hanya sambil lalu dalam menanggapi infografis tersebut karena konten dan visualiasasi kurang daya persuasif, dramatik dan kreatif

\section{KAJIAN LITERATUR}

\section{A. Infogafis Sebagai Sarana Komunikasi Visual dan Perkembangannya}

Pada awalnya Grafis Informasi (Infographics) dianggap hanya sebagai elemen visual seperti grafik, peta, atau diagram yang membantu pengertian dalam sebuah bacaan yang berbasis teks. Lalu infographic koran pada sebuah berita kecelakaan kemudian dianggap mampu "merekam" menggunakan visual, yang telah dijelaskan dalam teks yang mendampinginya (Simiciklas, 2012). Seiring dengan perkembangan teknologi digital infografis telah berkembang baik dalam wahana maupun bentuknya. Infografis konvensional kita kerap temui berupa poster, layer, dan karya dua dimensi yang bersifat statis, dan jenis infografis ini kurang strategis dan komunikatif di era dunia yang telah 'lipat' ini. Infografis kini telah menjalin relasi dengan dunia digital dan telah mengembangkan kemapuannya pada sifat yang dinamis atau visual moving dengan tidak menghilangkan subtansinya sebagai media informasi dan komunikasi.

Yulianto (2015, 117-202) dalam jurnal penelitian yang berjudul Grafis Informasi Dalam Komunikasi Visual menyebut bahwa Infografis adalah representasi visual informasi, data atau ilmu pengetahuan secara grafis. Infografis dapat memperlihatkan informasi rumit dengan singkat dan jelas, sehingga informasi lebih mudah dipahami oleh masyarakat. Lebih lanjut beberapa hal penting terkait dengan infografis merupakan; 1) Visualisasi cerita atau hasil penelitian yang berisi penuh tentang data. 2) Sebuah alat atau media untuk mengedukasi dan menyampaikan informasi. 3) Sebuah cara untuk membangun Brand awareness dan berhubungan dengan menghemat biaya standar kampanye pemasaran online.

Dari ruang lingkup tentang infografis yang telah dijelaskan di atas, infografis sangat memungkinkan untuk berkembang di era komunikasi digital hari ini. Infografi secara subtansi adalah bagaimana dapat menyampaikan informasi 
yang kompleks berdasarkan data dengan sajian visual yang menarik, sehingga memudahkan pembaca untuk mendapatkan informasi. Seperti yang dilakukan dalam penelitian artistik ini, karya ini merupakan sebuah pengembangan dari wahana infografis yang telah ada sebelumnya. Infografis dengan tema sosialisasi protokol kami kembangkan wahana dan mediumnya dengan pendekatan visual mapping, sehingga infografis terus berkembang dalam upaya menyebarkan informasi dan komunikasi yang tidak hanya informatif namun memiliki pengalaman baru berupa pengalaman visual dalam mendpatakan informasi.

\section{B. Video Mapping; Ruang Lingkup dan Teknis}

Video mapping merupakan pencapaian hasil teknologi inovatif yang bersifat dinamis. Teknik yang memproyeksikan gambar video pada bangunan, struktur atau hampir semua jenis permukaan atau objek 3D. Proyektor akan menyoroti setiap bentuk, garis atau ruang. Sehingga tercipta ilusi optik yang pada proyeksi objek pada bangunan. Video mapping cukup baru dan sangat berkembang saat ini. Alasan keberhasilannya adalah bahwa teknologi ini juga mampu menjadi wahana pertunjukan sehingga masyarakat akan terlibat secara emosional dalam pertunjukan.

Video Mapping merupakan teknologi rekayasa visual hasil dari perkembangan komputerisasi mutahir. Catanese (2013: 165) menyebut bahwa video mapping muncul sebagai teknik proyeksi mengubah permukaan apa pun (bangunan, permukaan, dan hampir semua jenis permukaan kompleks atau objek tiga dimensi) dalam tampilan dinamis: dari gambar besar di monumen atau fasad, hingga dunia virtual. Kita bisa mendefinisikannya sebagai teknik proyeksi permukaan tiga dimensi, yang memungkinkan kita untuk menjelajahi potensi kreatif dari teknologi digital sebagai sarana sinestetik.

Dalam sejarahnya video mapping, teknis ini dipengaruhi oleh teknik melukis: Trompe L'Oeil yang digunakan sejak Yunani dan Roma, merke mendekorasi rumah mereka, membuat dekorasi (modal yang dicat marmer harganya kurang dari marmer asli), dan untuk memperluas lingkungan tertutup secara virtual, pada saat yang bersamaan (Catanese, 2013: 166). Melihat dari sejarahnya itu memang video mapping menjadi seni perparpaduan antara seni rupa dan arsitektur dengan bantuan teknlogi optic dan digital.

Video mapping selain sebagai media komunikasi visual turut menghadirkan suasana pertunjukan dalam penyajiannya. Proyeksi video yang ditembakkan seturut dengan tekstur objek bangunan memberikan pengalaman bagi penonton untuk menyakisikan visual yang hadir dalam objek banguanan. Pada titik ini, Karya video mapping merupakan perpaduan dari unsur film, video dan pertunjukan, sehingga pada umumnya mensyrakatkan penonton langsung.

Teknis dari video mapping cukup kompleks, karena mensyaratkan interlasi dari berbagi aspek. Dalam proses produksi video seni ini, ada beberapa tahapan penting yang dilakukan secara cermat. Setup merupakan tahapan persiapan yang bersifat teknis. Persiapaan yang dilakukan meliputi peralatan yang akan digunakan dalam pengambilan gambar. Tahapan ini biasa disebut tahap praproduksi. Tahapan selanjutnya adalah tahapan produksi, yaitu pengambilan gambar yang kemudian diolah secara digital dengan menggunakan software editing dan animasi untuk menciptakan efek-efek yang ingin ditampilkan. Seperti halnya tahap penciptaan sebuah karya audiovisual lainnya, pascaproduksi adalah bagian yang sangat menentukan hasil akhir dari sebuah karya video. Tahap ini merupakan tahap penyempurnaan dan penyelesaian baik dari segi audio maupun video. Pascaproduksi merupakan tahapan akhir yang dilakukan untuk menggabungkan, memotong, dan membangun audio visual berdasarkan naskah atau konsep cerita. Audio merupakan salah satu elemen yang memiliki peranan penting dalam memperkuat emosi penonton, mood, dan nuansa dalam sebuah video.

Dalam karya video ini dipilih ilustrasi musik yang diharapkan mampu membangun suasana ketika video diputar di dalam ruangan yang gelap. Kesemua tahapan ini harus dilalui sehingga menghasilkan karya video yang kemudian bisa diimplementasikan ke dalam bentuk display video sesuai dengan keinginan penulis. 


\section{METODE PENELITIAN}

Penelitian artistik memiliki karakteristik utama, yang tidak terdapat dalam penelitian lain, yakni sifatnya yang sangat personal, berpusat pada praktik kreatif itu sendiri. Artinya, para peneliti artistik harus mengacu pada tujuan membentuk wacana seni atau desain dari praktik kreatif seniman atau desainer itu sendiri (Pedgley, 2007: 464). Penelitian seni tidak ada standar kemasan metode baku yang dapat ikuti oleh peneliti. Gray dan Malins menyebutkan bahwa penelitian seni (dan desain) melibatkan beragam metode, utamanya visual, yang berasal dari praktik atau diadaptasi untuk penelitian seni dari paradigma penelitian lain (Gray \& Marlins, 2004: 31).

Konsep metode penciptaan karya ini pada intinya adalah penyampaian informasi grafis (infografis) seputar upaya pencegahan Covid-19 dengan pendekatan dokumentasi video projection mapping. Dokumentasi video projection mapping adalah metode baru yang merupakan bagian dari evolusi seni visual. Sebagai manifestasi pencitraan seni visual dan teknologi. Video maker dapat mewujudkan ide yang didesain ke dalam materi 3D apapun di dalam bentukan arsitektur. Projection mapping menggabungkan pemetaan film dan video lalu didokumentasikan ulang. Video Mapping yang direncanakan berbeda dengan video mapping pada umumnya secara penyajiannya. Umumnya video mapping kita bisa saksikan hanya di tempat-tempat umum atau artsitektur bangunan namun dalam perencanaan video projection mapping kali ini berbeda, aktivitas pemutaran video mapping akan di dokumentasikan dalam bentuk video, lalu akan di share melalui kanal-kanal media social online. Sehingga kita dapat menyaksikan projection mapping dalam genggaman gawai di mana pun kita berada.

Proses tersebut mengandaikan dua aktivitas, yaitu pemutaran video projection mapping secara langsung di lokasi yang telah dipilih lantas kemudian didokumentasikan. Hasil dari dokumetasi video projection mapping akan bisa ditonton pada perangkat gadget melalui akunakun media social online. Melalui kanal media sosial masyarakat dapat menikmati hasil ekplorasi dokumentasi video mapping yang berisi materi dan informasi terkait kebijakan-kebijakan pemerintah dalan penanggulangan pandemi Covid-19 serta protokol kesehatan resmim dari pemerintah. Media baru ini diharapkan memberikan informasi grafis melalui seni visual atau video alternativ, dan lebih dinamis dibandingkan informasi grafis yang ditampilkan melalui video konvensional seperti poster yang kerap membosankan karena bersifat statis.

\section{HASIL DAN PEMBAHASAN}

Rancangan penelitian artitik karya Video Projection Mapping ini yaitu mengelaborasi dari tahapan karya dengan sumber data yang digunakan dasar dalam membuat karya. Berikut skema rancangan karya Infografis Video Mapping tentang sosialisasi Covid-19:

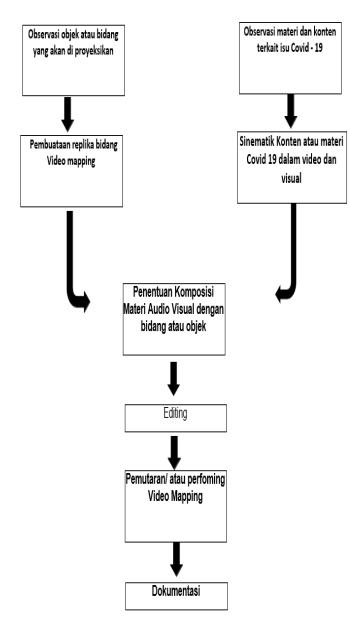

Bagan 1. Skema Perancangan Karya

Penelitian artistik ini mengahasilkan sebuah desain video mapping yang memuat materi infografis terkait sosialisasi protokol kesehatan. Desain video mapping ini memuat konten-konten perpaduan antara visual animasi, visual moving, dan establish kota Solo sebagai sasaran informasi terkait Covid-19. Selain itu konten terkait dengan kebijakan ditampilkan dengan narasi-narisi teks kemudian ditambah data-data visual dari kebijakan pemerintahan dalam hal ini walikota Solo. Desain Video mapping ini memadukan konsep tradisi dalam sebuah infografis terkait covid-19. Konten-konten tradisi penting dihadirkan untuk tetap menemukan identitas lokal dalam sebuah infografis. 
Di sisi lain, konten tradisi juga menjadi srategi untuk menarik perhatian audiens dalam proses penerimaan informasi. Berikut desain struktur video mapping inforgafis Covid-19:

\section{Struktur dan Materi Video Mapping}

Struktur video mapping ini tidak menggunakan alur yang ketat, materi disusun berdasarkan hasil kolabaroasi antara konten tradisi dengan infografis Covid-19. Keduanya susul menyusul menjadi perpaduan harmonis pengantar infografis dan ilustrasi yang menjadi back sound dan moving visualnya. Pada bagian konten terdiri konten tradisi sebagai gimmick, ilustrasi tentang Covid, establishing Kota Solo dan konten infografis yang berisi informasi dan sosialisasi terkait dengan Covid-19.

\section{Konten Tradisi}

Konten tradisi yang dihadirkan dalam video mapping ini memuat batik, keris, dan wayang sebagai simbolisasi dari identitas Kota Solo. Batik, keris, dan wayang dieloborasikan secara mozaik di bagain awal. Gimmick dengan konten tradisi diharapkan mampu memberikan idenititas dan kekhasan sebuah karya infografis, sehingga diharapakan penerima informasi ini lebih didekatkan dengan budaya setempat yang menjadi kebanggaaan masyarakat Kota Solo.

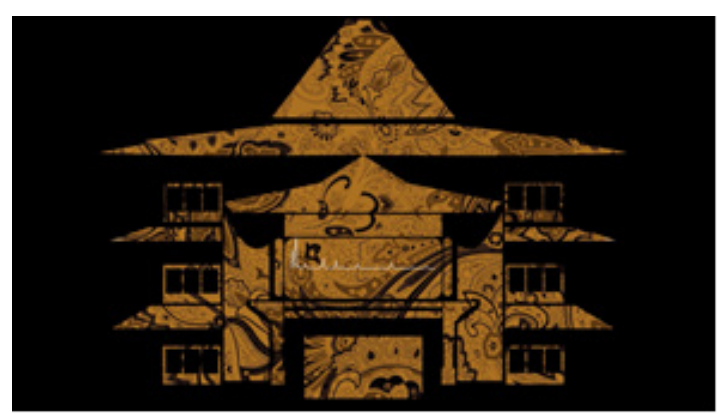

Gambar 2. Konten Tradisi Pada Video Mapping dengan konten tradisi. (Foto, NRA. Candra, 2020)

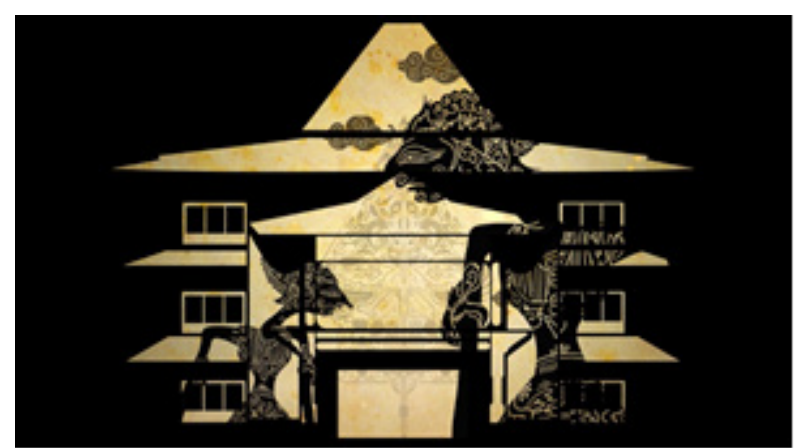

Gambar 3. Konten Tradisi gimmick Video Mapping dengan konten tradisi. (Foto, NRA. Candra, 2020)
Konten tradisi yang dihadirkan dalam video mapping ini memuat batik, keris, dan wayang sebagai simbolisasi dari identitas Kota Solo. Batik, keris, dan wayang dieloborasikan secara mozaik di bagain awal. Gimmick dengan konten tradisi diharapkan mampu memberikan idenititas dan kekhasan sebuah karya infografis, sehingga diharapakan penerima informasi ini lebih didekatkan dengan budaya setempat yang menjadi kebanggaaan masyarakat Kota Solo.

\section{Konten Ilustrasi Covid-19}

Setelah gimiick dengan konten tradisi konten selanjutnya adalah ilustrasi tentang Covid-19. Ilustrasi Covid dihadirkan berupa simbolisasi visual virus yang bergerak secara bebas, visual moving bertujuan meberi gambaran bahwa virus Covid-19 ada di sekitar kita secara bebas sehingga informasi ini memberi penekanan pada masyarakat untuk selalu waspada.

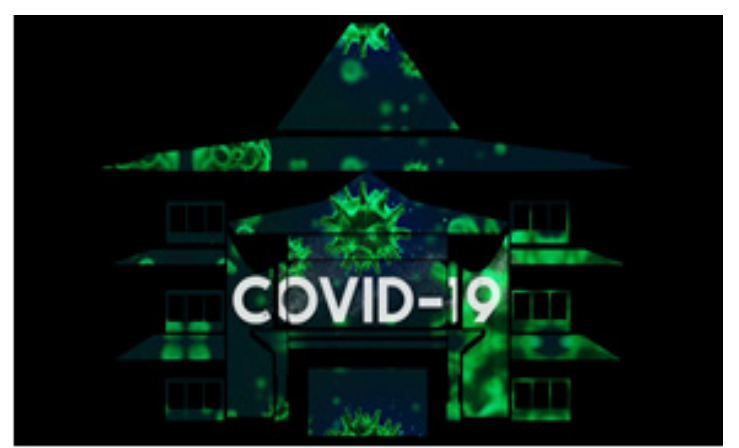

Gambar 4. Konten Ilustrasi Covid-19 Pada Video Mapping (Foto, NRA. Candra, 2020)

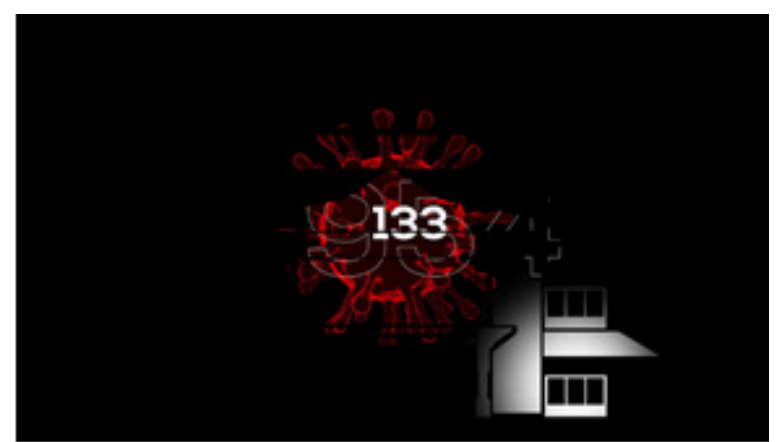

Gambar 5. Konten Ilustrasi Covid-19 Pada Video Mapping. (Foto, NRA. Candra, 2020)

\section{Konten Establishing Kota Solo}

Establish yang dipilih adalah lokasi-lokasi strategi yang menjadi ikon kota Solo, seperti patung keris, pasar klewer dan area Bank 
Indonesia. Establis ini memperkuat bahwa infografis ini menjadi sebuah sarana khususnya masyarakat Kota Solo.

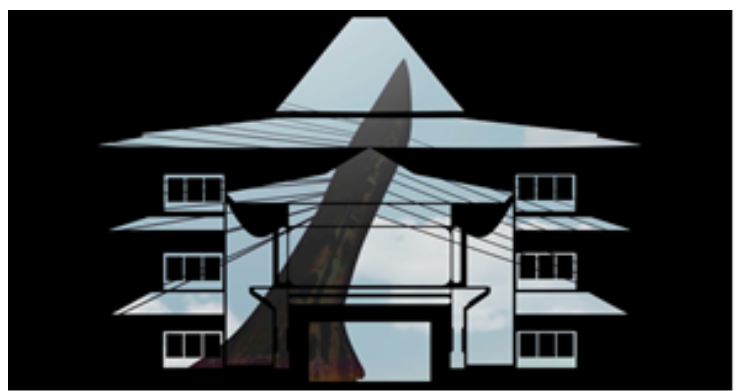

Gambar 6. Konten Establish Covid-19 Pada Video Mapping. (Foto, NRA. Candra, 2020)

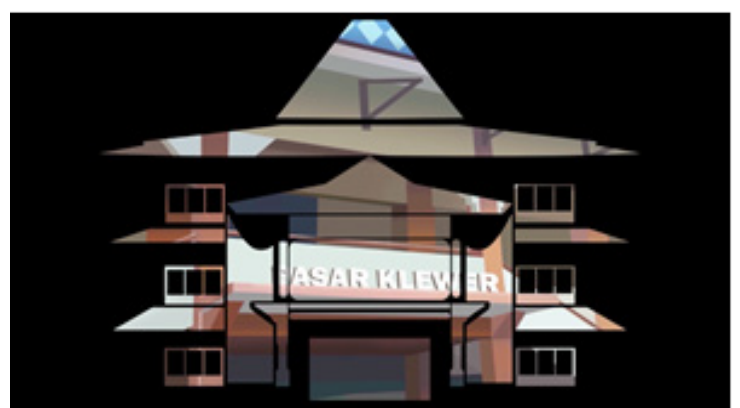

Gambar 7. Konten Establish Covid-19 Pada Video Mapping. (Foto, NRA. Candra, 2020)

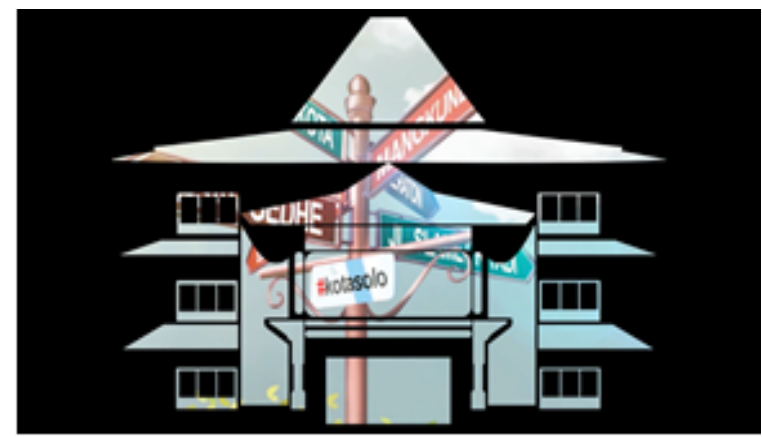

Gambar 7. Konten Establish Pada Video Mapping (Foto, NRA. Candra, 2020)

\section{Konten Infografis Protokol Covid-19}

Konten Infografis Protokol kesehatan terkait Covid-19 ini menjadi fokus utama mapping kali ini. Infografis itu disusun berdasarkan data terkait bagaiamana pencegahan dan penularan Covid-19.

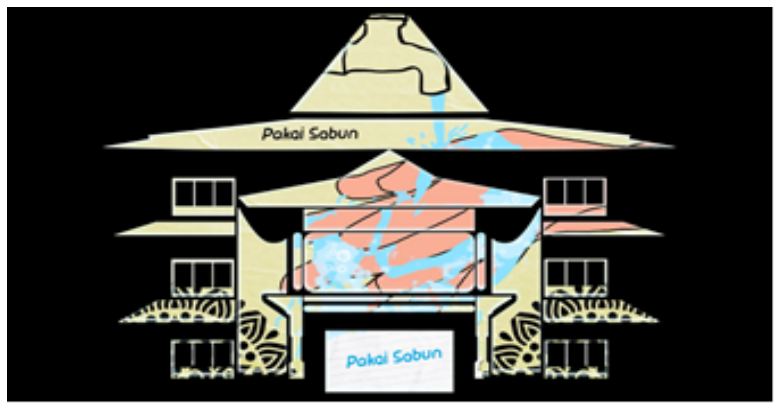

Gambar 8. Konten Infografis Protokol Kesehatan Pada Video Mapping (Foto, NRA Candra, 2020)

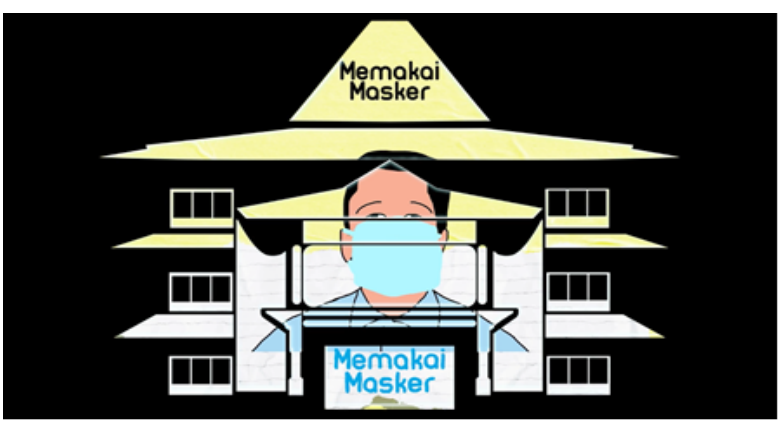

Gambar 9. Konten Infografis Protokol Kesehatan Pada Video Mapping.(Foto, NRA Candra, 2020)

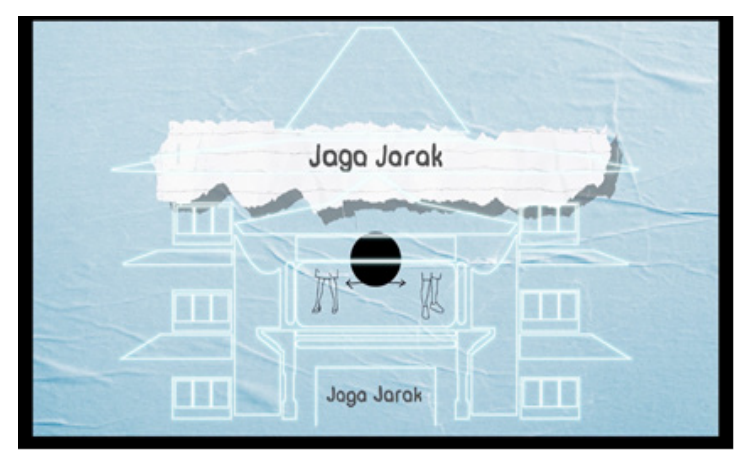

Gambar 10. Konten Infografis Protokol Kesehatan Pada Video Mapping. (Foto, NRA. Candra, 2020)

\section{KESIMPULAN}

Konsep metode penciptaan karya ini pada intinya adalah penyampaian informasi grafis (infografis) seputar upaya pencegahan Covid-19 dengan pendekatan dokumentasi video projection mapping. Dokumentasi video projection mapping adalah metode baru yang merupakan bagian dari evolusi seni visual. Sebagai manifestasi pencitraan seni visual dan teknologi. Video maker dapat mewujudkan ide yang didesain ke dalam materi 3D apapun di dalam bentukan arsitektur. Projection mapping 
menggabungkan pemetaan film dan video lalu didokumentasikan ulang. Aktivitas pemutaran video mapping didokumentasikan dalam bentuk video, lalu akan di share melalui kanalkanal media social online. Sehingga kita dapat menyaksikan hasil video projection mapping dalam genggaman gawai di mana pun kita berada.

Karya ini juga berangkat dari penelitian tentang kebijakan sosialisasi Covid-19 dan praktik-praktik sosialisasi Covid-19 di berbagai media dalam bentuk audio visual. Tujuan utamanya adalah memberikan alternatif media sosialisasi yang selama ini masih kurang efektif karena konten yang terlalu sederhana dan ilustratif. Dengan media video mapping, diharapkan sosialisasi lebih memberi penekanan pada aspek komunikatif dan persuasif karena konten yang dinamis dan kreatif.

Video mapping menjadi alternatif baru dalam media komunikasi visual. Video Mapping menawarkan pengalaman baru dalam penerimaan informasi. Sehingga selain menjadi media informasi, karya ini juga menjadi karya estetik dalam upaya pengembangan dan eskplorasi teknik video projection mapping.

\section{DAFTAR PUSTAKA}

Gray, Carole and Malins, Julian. Visualizing Research: A Guide to the Research Process in Art and Design. Burlington: Ashgate Publishing Company. 2004

Miles, Matthew B. \& A. Michael Huberman Analisis Data Kualitatif. Terj. Tjetjep Rohendi Rohidi.Jakarta: UniversitasIndonesia UI Press, 1992

Moleong, Lexy J. Metode Penelitian Kualitatif. Bandung: Remaja Rosdakarya, 2010. Pedgley, Owain . "Capturing and analysing own design activity". Design Studies, Vol. 28, No. 5 September, pp: 463-483. 2007.

Putra, Emka Satya, Deny Tri Ardianto,, Dipl. Art, Erandaru, Laporan Kekaryaan. Perancangan Projection Mapping Rumah
Wafat W.R. Supratman. Universitas Kristen Petra

R. Catanese. 3D ARCHITECTURAL VIDEOMAPPING. International Archives of the Photogrammetry, Remote Sensing and Spatial Information Sciences, Volume XL-5/W2, 2013 XXIV International CIPA Symposium, 2 - 6 September 2013, Strasbourg, France

Ratna, Nyoman Kutha. Metode Penelitian: Kajian Budaya dan IImu Sosial Humaniora Pada Umumya. Yogyakarta. Pustaka Pelajar, 2010.

Rohidi, Tjetjep Rohendi. Metode Penelitian Seni. Semarang: Cipta Prima Nusantara, 2012.

Sya'Roni, Ahmad Khotib. Laporan Kekaryaan. Video Mapping Bandung Lautan Api Sebagai Media Edukasi Sejarah. Universitas Telkom:Bandung.

\section{Internet}

https://nasional.tempo.co/read/1321285/pandemi-corona-ribuan-orangikut-tabligh-akbarse-asia-di- gowa

https://www.kemkes.go.id.www.slideshare.net https://www.slideshare.net

D Hariyadi, (2020, Maret 18). Pandemi Corona, Ribuan Orang Ikut Tabligh Akbar se-Asia di Gowa. Tempo.co. Diakses dari https://nasional. tempo .co/read/1321285/pandemi-corona-ribuan-orangikut- tabligh-akbar-seasia-di-gowa, pukul 20.00 WIB 